Provided for non-commercial research and education use. Not for reproduction, distribution or commercial use.

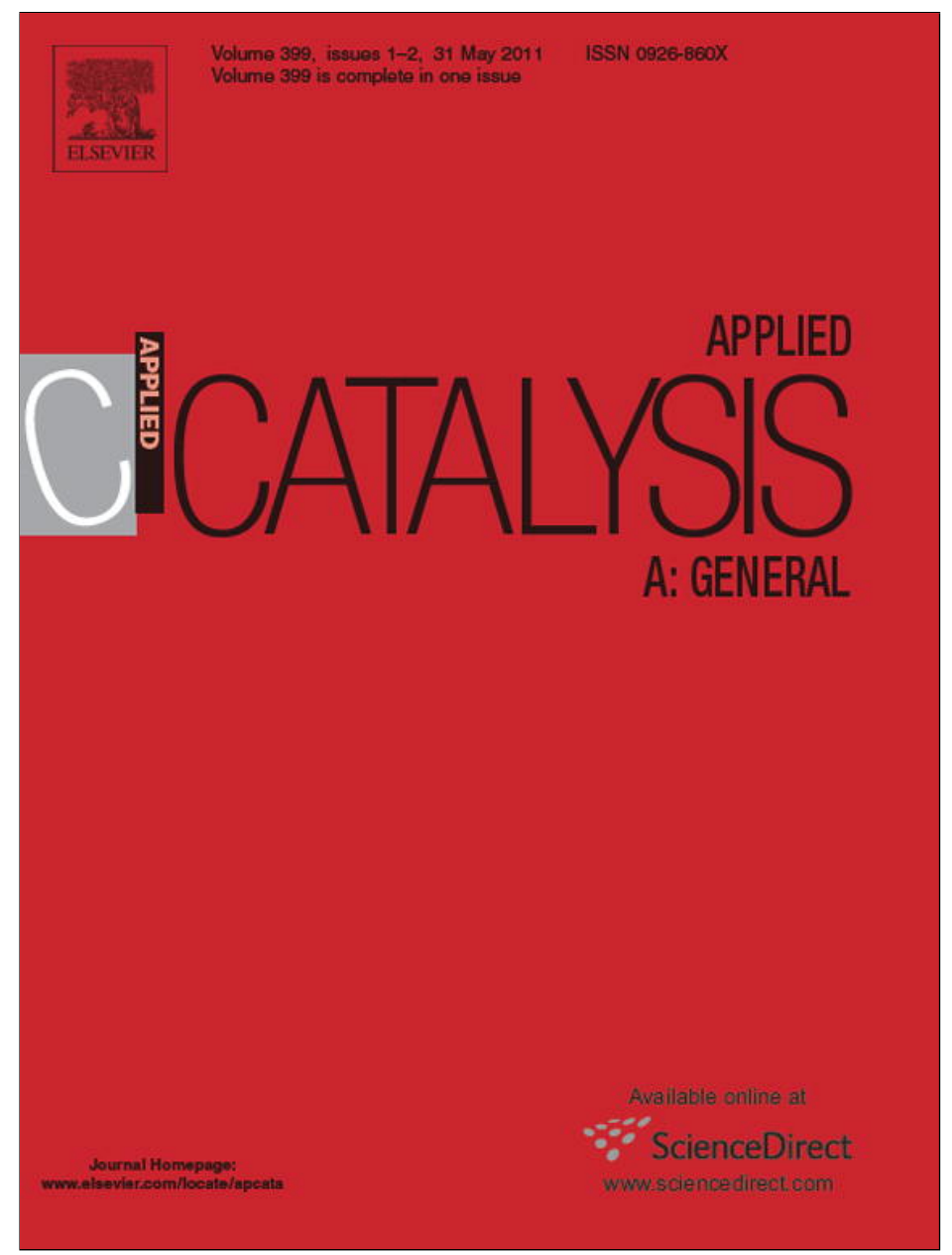

This article appeared in a journal published by Elsevier. The attached copy is furnished to the author for internal non-commercial research and education use, including for instruction at the authors institution and sharing with colleagues.

Other uses, including reproduction and distribution, or selling or licensing copies, or posting to personal, institutional or third party websites are prohibited.

In most cases authors are permitted to post their version of the article (e.g. in Word or Tex form) to their personal website or institutional repository. Authors requiring further information regarding Elsevier's archiving and manuscript policies are encouraged to visit:

http://www.elsevier.com/copyright 


\title{
Simple and efficient water soluble thioligands for rhodium and iridium catalyzed biphasic hydrogenation
}

\author{
Sabrina Di Dio ${ }^{\mathrm{a}}$, Mauro Marchetti ${ }^{\mathrm{b}}$, Stefano Paganelli ${ }^{\mathrm{a}, *}$, Oreste Piccolo ${ }^{\mathrm{a}, \mathrm{c}}$ \\ a Dipartimento di Scienze Molecolari e Nanosistemi, Università Ca' Foscari Venezia, Calle Larga Santa Marta 2137, 30123 Venezia, Italy \\ ${ }^{\mathrm{b}}$ Sede di Sassari dell'Istituto di Chimica Biomolecolare del CNR, trav. La Crucca 3, Reg. Baldinca - Li Punti, 07040 Sassari, Italy \\ c Studio di Consulenza Scientifica, via Bornò 5, 23896 Sirtori (LC), Italy
}

\section{A R T I C L E I N F O}

\section{Article history:}

Received 25 November 2010

Received in revised form 31 March 2011

Accepted 3 April 2011

Available online 12 April 2011

\section{Key words:}

Rhodium

Iridium

Biphasic hydrogenation

Catalyst

Water soluble ligand

\begin{abstract}
A B S T R A C T
The activity of catalytic systems derived from the interaction between $\mathrm{Rh}(\mathrm{CO})_{2} \mathrm{acac}$ and $[\operatorname{Ir}(\mathrm{COD}) \mathrm{Cl}]_{2}$, respectively, with the water soluble thioligands (L)-Cysteine (1) and (S)-Captopril (2), was tested in the aqueous biphasic hydrogenation of some representative $\alpha, \beta$-unsaturated compounds as 2 -cyclohexen1-one (I), trans-cinnamaldehyde $(\mathbf{V})$ and [3-(1,3-benzodioxol-5-yl)-2-methylpropenal] $(\mathbf{X})$, precursor of the fragrance Helional ${ }^{\circledR}(\mathbf{X I})$. The precatalyst $\mathbf{R h} /$ Cap was able to hydrogenate cyclohexenone even at low pressure at $60^{\circ} \mathrm{C}$ in a neutral medium while $\mathbf{R h} / \mathbf{C y}$ required either higher pressure and temperature or an alkaline medium. The iridium based catalysts, Ir/Cy and Ir/Cap, showed an analogous trend though their activities were lower than those of the related rhodium catalysts. All the catalysts were easily recycled without significant loss of activity. The rhodium catalysts were also used in the hydrogenation of the above aldehydes $\mathbf{V}$ and $\mathbf{X}$ and their activity was strongly enhanced when ethylene glycol was used as organic solvent or co-solvent.
\end{abstract}

C 2011 Elsevier B.V. All rights reserved.

\section{Introduction}

Catalytic biphasic reactions are widely used because of their advantages over conventional homogeneous catalytic syntheses as the easy separation and reuse of the expensive catalyst and the environmental aspects of the chemical process [1-3]. In particular, aqueous/organic biphasic reactions, that employ water-soluble catalysts, are increasingly attractive and many water soluble ligands and/or surfactants have been employed in catalytic reactions [1-10].

Recently, we reported a highly efficient and chemoselective hydrogenation reaction using water soluble complexes derived from the interaction between $\mathrm{Rh}(\mathrm{CO})_{2}(\mathrm{acac})$ and $[\operatorname{Ir}(\mathrm{COD}) \mathrm{Cl}]_{2}$, respectively, with human serum albumin (HSA) [11]. Previous studies, carried out by us on the catalytic system Rh/HSA, showed an outstanding correspondence between the surface distribution of $\mathrm{Rh}$ and $\mathrm{S}$ atoms of the protein, therefore we hypothesized that the metal atom mainly interacts with the sulfur atoms [12,13]: the great affinity of "soft" metals, such as rhodium, for the thiolic group is well known [14]. Encouraged by these results, we turned our attention to simpler and cheaper water soluble thioligands capable of promoting efficiently the hydrogenation process

\footnotetext{
* Corresponding author. Tel.: +39 0412348592; fax: +39 0412348517.

E-mail address: spag@unive.it (S. Paganelli).
}

and, at the same time, allowing easy recovery and recycling of the water soluble catalytic complex. Then, we extended our research work to the aqueous biphasic hydrogenation of some model substrates in the presence of rhodium and iridium complexes modified with simpler ligands than HSA, such as the aminoacid (L)-Cysteine (1) and (S)-Captopril (2) (Fig. 1). (L)-Cysteine is a component of human serum albumin itself, while (S)-Captopril, [(S)-1-[(S)3-mercapto-2-methylpropanoyl]pyrrolidine-2-carboxylic acid], is a pharmacologically active ACE inhibitor, easily available at low price. The catalytic complexes were prepared in situ by reacting $\mathrm{Rh}(\mathrm{CO})_{2}$ (acac) and $[\operatorname{Ir}(\mathrm{COD}) \mathrm{Cl}]_{2}$, respectively, with (L)-Cysteine $(\mathbf{R h} / \mathbf{C y}$ and $\mathbf{I r} / \mathbf{C y})$ or with (S)-Captopril (Rh/Cap and Ir/Cap) and the aqueous solutions obtained used as catalytic phase in the biphasic hydrogenation of some $\alpha, \beta$-unsaturated substrates as 2-cyclohexen-1-one (I), trans-cinnamaldehyde (V) and [3-(1,3benzodioxol-5-yl)-2-methylpropenal] (X).

\section{Experimental}

\subsection{General remarks}

$\mathrm{Rh}(\mathrm{CO})_{2}$ (acac) and $[\mathrm{Ir}(\mathrm{COD}) \mathrm{Cl}]_{2}$ were obtained by Strem Chemicals, Inc. 2-Cyclohexen-1-one, trans-cinnamaldehyde, (L)-Cysteine, phosphate buffer solution ( $\mathrm{pH} 7.2$ ) and boric acid-potassium chloride-sodium hydroxide buffer solution ( $\mathrm{pH} 10.0$ ) were Aldrich products. 3-(1,3-Benzodioxol-5-yil)-2-methyl-propenal was syn- 
<smiles>N[C@H](CS)C(=O)O</smiles>

1<smiles>C[C@H](CS)C(=O)N1CCC[C@H]1C(=O)O</smiles>

2
Fig. 1. (L)-Cysteine (1) and (S)-Captopril (2).

thesized as described in the literature [15]. (S)-Captopril was a generous gift of Prochifar srl (Milan). ${ }^{1} \mathrm{H}$ NMR and ${ }^{13} \mathrm{C}$ NMR spectra were recorded on a Bruker Avance 300, using $\mathrm{D}_{2} \mathrm{O}$ as solvent. GC analyses were carried out on an Agilent 6850A gaschromatograph and GC-MS analyses were performed by using an Agilent MS Network 5937. IR spectra were recorded on an FTIR Nicolet Magna 750 instrument. Solvents were purified as described in the literature [16].

\subsection{Catalyst preparation}

The catalytic complexes $\mathbf{R h} / \mathbf{C y}, \mathbf{I r} / \mathbf{C y}, \mathbf{R h} / \mathbf{C a p}$ and $\mathbf{I r} / \mathbf{C a p}$ were prepared in situ by reacting, at room temperature, $\mathrm{Rh}(\mathrm{CO})_{2}$ (acac) $(2.7 \mathrm{mg}, 0.0104 \mathrm{mmol})$ and $\left[\operatorname{Ir}(\mathrm{COD}) \mathrm{Cl}_{2}(3.5 \mathrm{mg}, 0.0052 \mathrm{mmol})\right.$, respectively, with (L)-Cysteine $(2.5 \mathrm{mg}, 0.0208 \mathrm{mmol})$ or with (S)Captopril $(4.2 \mathrm{mg}, 0.0208 \mathrm{mmol})$, in $4 \mathrm{ml}$ of disareated aqueous buffer solution ( $\mathrm{pH} 7.2$ or 10$)$, until complete dissolution of the complex.

\subsection{Catalyst characterization}

In order to have some information on the structure of the catalytic systems $\mathbf{R h} / \mathbf{C y}$ and $\mathbf{R h} / \mathbf{C a p}$, NMR spectra were recorded by using a Bruker Avance 300 spectrometer working at $300 \mathrm{MHz}$. Both samples were prepared by dissolving, in disareated $\mathrm{D}_{2} \mathrm{O}$, $\mathrm{Rh}(\mathrm{CO})_{2} \mathrm{acac}(2.7 \mathrm{mg}, 0.0104 \mathrm{mmol})$ and (L)-Cysteine $(2.5 \mathrm{mg}$, $0.0208 \mathrm{mmol}$ ) or (S)-Captopril ( $4.5 \mathrm{mg}, 0.0208 \mathrm{mmol}$ ), respectively. NMR spectra of both free thioligands in $\mathrm{D}_{2} \mathrm{O}$ were carried out, too. FT-IR spectra ( $\mathrm{KBr}$ pellet) of $\mathbf{R} \mathbf{h} / \mathbf{C} \mathbf{y}$ and of the free aminoacid (L)-Cysteine, in the range of $4000-600 \mathrm{~cm}^{-1}$, were also recorded. The sample of $\mathbf{R h} / \mathbf{C y}$ was obtained by dissolving in disareated water $\mathrm{Rh}(\mathrm{CO})_{2}$ acac ( $2.7 \mathrm{mg}, 0.0104 \mathrm{mmol}$ ) and (L)-Cysteine $(2.5 \mathrm{mg}$, $0.0208 \mathrm{mmol}$ ) and, after removal of the water, it was dried under vacuum. The data obtained in both NMR and IR spectra are reported and discussed in Section 3.1.

\subsection{Aqueous biphasic hydrogenation experiments}

All reactions were carried out following the procedure below described for the $\mathbf{R h}$ /Cap catalyzed hydrogenation of 2-cyclohexen1-one (I). Experimental details for all the hydrogenations are reported in Tables 1-9.

\subsubsection{Aqueous biphasic hydrogenation of 2-cyclohexen-1-one (I) catalyzed by $\mathbf{R h} / \mathbf{C a p}$ at $\mathrm{pH} 7.2$}

In a Schlenk tube, $2.7 \mathrm{mg}(0.0104 \mathrm{mmol})$ of $\mathrm{Rh}(\mathrm{CO})_{2} \mathrm{acac}$ and $4.5 \mathrm{mg}(0.0208 \mathrm{mmol})$ of $(\mathrm{S})$-captopril (metal/thioligand $=1 / 2$ molar ratio) were stirred under nitrogen in $4 \mathrm{~mL}$ of disareated aqueous phosphate buffer solution ( $\mathrm{pH}$ 7.2) until complete dissolution of the complex. A solution of $500 \mathrm{mg}(5.2 \mathrm{mmol})$ of 2-cyclohexen-1one (I) in $2 \mathrm{~mL}$ of toluene was then added to the aqueous phase. The Schlenk tube was then transferred into a $150 \mathrm{~mL}$ stainless steel autoclave under nitrogen, pressurized with $5 \mathrm{MPa}$ of $\mathrm{H}_{2}$ and stirred for $1 \mathrm{~h}$ at $60^{\circ} \mathrm{C}$ (Table 3 ). The reactor was then cooled to room temperature and the residual gases released. The organic
Table 1

Aqueous biphasic hydrogenation of 2-cyclohexen-1-one (I) catalyzed by $\mathbf{R h} / \mathbf{C y}$ at $\mathrm{pH} 7.2$.

\begin{tabular}{clll}
\hline Run & $T\left({ }^{\circ} \mathrm{C}\right)$ & Conv. $(\%)$ & II yield $(\%)$ \\
\hline 1 & 60 & 13 & 13 \\
$2^{\mathrm{a}}$ & 60 & 14 & 14 \\
$3^{\mathrm{a}}$ & 60 & 13 & 13 \\
$4^{\mathrm{a}}$ & 60 & 19 & 19 \\
5 & 80 & 64 & 64 \\
$6^{\mathrm{a}}$ & 80 & 96 & 96 \\
$7^{\mathrm{a}}$ & 80 & 99 & 99 \\
$8^{\mathrm{a}}$ & 80 & 99 & 99 \\
$9^{\mathrm{a}}$ & 80 & 99 & 99 \\
$10^{\mathrm{a}}$ & 80 & 97 & 97 \\
\hline
\end{tabular}

Substrate $=5.2 \mathrm{mmol}$; substrate $/ \mathrm{Rh}$ (molar ratio) $=500 / 1 ; \mathrm{Rh} /(\mathrm{L})$-Cysteine (molar ratio $)=1 / 2$; aqueous buffer sol. $/$ toluene $=4 / 2 \mathrm{ml} ; \mathrm{p}\left(\mathrm{H}_{2}\right)=5 \mathrm{MPa} ; t=21 \mathrm{~h}$.

a Reaction carried out by using the aqueous phase recovered from the previous run.

Table 2

Aqueous biphasic hydrogenation of 2-cyclohexen-1-one (I) catalyzed by $\mathbf{R h} / \mathbf{C y}$ at pH 10.

\begin{tabular}{ccccc}
\hline Run & $t(\mathrm{~h})$ & Conv. $(\%)$ & II yield $(\%)$ & III yield $(\%)$ \\
\hline 1 & 6 & 24 & 24 & - \\
$2^{\mathrm{a}}$ & 6 & 32 & 32 & - \\
$3^{\mathrm{a}}$ & 6 & 35 & 35 & - \\
$4^{\mathrm{a}}$ & 6 & 35 & 35 & - \\
$5^{\mathrm{a}}$ & 6 & 32 & 32 & - \\
$6^{\mathrm{a}}$ & 6 & 31 & 31 & - \\
7 & 21 & 100 & 100 & - \\
$8^{\mathrm{a}}$ & 21 & 100 & 92 & 8 \\
$9^{\mathrm{a}}$ & 21 & 100 & 89 & 9 \\
$10^{\mathrm{a}}$ & 21 & 100 & 91 & 12 \\
$11^{\mathrm{a}}$ & 21 & 100 & 88 & 18 \\
$12^{\mathrm{a}}$ & 21 & 100 & 82 & \\
\hline
\end{tabular}

Substrate $=5.2 \mathrm{mmol}$; substrate $/ \mathrm{Rh}$ (molar ratio) $=500 / 1 ; \mathrm{Rh} /(\mathrm{L})$-Cysteine (molar ratio $)=1 / 2$; aqueous buffer sol./toluene $=4 / 2 \mathrm{ml} ; \mathrm{p}\left(\mathrm{H}_{2}\right)=5 \mathrm{MPa} ; T=60^{\circ} \mathrm{C}$

a Reaction carried out by using the aqueous phase recovered from the previous run.

Table 3

Aqueous biphasic hydrogenation of 2-cyclohexen-1-one (I) catalyzed by Rh/Cap at $\mathrm{pH} 7.2$.

\begin{tabular}{ccclc}
\hline Run & $t(\mathrm{~h})$ & Conv. $(\%)$ & II yield $(\%)$ & III yield $(\%)$ \\
\hline 1 & 1 & 70 & 70 & - \\
$2^{\mathrm{a}}$ & 1 & 90 & 90 & - \\
$3^{\mathrm{a}}$ & 1 & 88 & 88 & - \\
$4^{\mathrm{a}}$ & 1 & 85 & 85 & - \\
$5^{\mathrm{a}}$ & 1 & 85 & 85 & - \\
6 & 21 & 100 & 68 & 32 \\
$7^{\mathrm{a}}$ & 21 & 100 & 61 & 39 \\
$8^{\mathrm{a}}$ & 21 & 100 & 79 & 21 \\
$9^{\mathrm{a}}$ & 21 & 100 & 81 & 19 \\
$10^{\mathrm{a}}$ & 21 & 100 & 88 & 12
\end{tabular}

Substrate $=5.2 \mathrm{mmol}$; substrate $/ \mathrm{Rh}($ molar ratio) $=500 / 1 ; \mathrm{Rh} /(\mathrm{S})$-Captopril (molar ratio) $=1 / 2$; aqueous buffer sol./toluene $=4 / 2 \mathrm{ml} ; \mathrm{p}\left(\mathrm{H}_{2}\right)=5 \mathrm{MPa} ; T=60^{\circ} \mathrm{C}$.

a Reaction carried out by using the aqueous phase recovered from the previous run.

\section{Table 4}

Aqueous biphasic hydrogenation of 2-cyclohexen-1-one (I) catalyzed by Rh/Cap at $\mathrm{pH} 7.2$ and $\mathrm{p}\left(\mathrm{H}_{2}\right)=0.5 \mathrm{MPa}$.

\begin{tabular}{lcc}
\hline Run & Conv. $(\%)$ & II yield (\%) \\
\hline 1 & 100 & 100 \\
$2^{\mathrm{a}}$ & 100 & 100 \\
$3^{\mathrm{a}}$ & 96 & 96 \\
$4^{\mathrm{a}}$ & 83 & 83 \\
$5^{\mathrm{a}}$ & 75 & 75
\end{tabular}

Substrate $=5.2 \mathrm{mmol}$; substrate $/ \mathrm{Rh}$ (molar ratio) $=500 / 1 ; \mathrm{Rh} /(\mathrm{S})$-Captopril (molar ratio $)=1 / 2$; aqueous buffer sol. $/$ toluene $=4 / 2 \mathrm{ml} ; \mathrm{p}\left(\mathrm{H}_{2}\right)=0.5 \mathrm{MPa} ; T=60^{\circ} \mathrm{C} ; t=21 \mathrm{~h}$. a Reaction carried out by using the aqueous phase recovered from the previous run. 
Table 5

Aqueous biphasic hydrogenation of 2-cyclohexen-1-one (I) catalyzed by $\mathbf{I r} / \mathbf{C y}$ at $\mathrm{pH}$ 10 .

\begin{tabular}{lclc}
\hline Run & Conv. (\%) & II yield (\%) & III yield (\%) \\
\hline 1 & 75 & 67 & 8 \\
$2^{\text {a }}$ & 100 & 82 & 18 \\
$3^{\text {a }}$ & 100 & 79 & 21 \\
$4^{\text {a }}$ & 100 & 77 & 23 \\
$5^{\text {a }}$ & 96 & 82 & 14 \\
\hline
\end{tabular}

Substrate $=5.2 \mathrm{mmol} ;$ substrate $/ \mathrm{Ir}$ (molar ratio) $=500 / 1 ; \mathrm{Ir} /(\mathrm{L})$-Cysteine (molar ratio $)=1 / 2$; aqueous buffer sol./toluene $=4 / 2 \mathrm{ml} ; \mathrm{p}\left(\mathrm{H}_{2}\right)=5 \mathrm{MPa} ; T=80^{\circ} \mathrm{C} ; t=21 \mathrm{~h}$.

a Reaction carried out by using the aqueous phase recovered from the previous run.

Table 6

Aqueous biphasic hydrogenation of trans-cinnamaldehyde ( $\mathbf{V}$ ) catalyzed by $\mathbf{R h} / \mathbf{C} \mathbf{y}$ at $\mathrm{pH} 7.2$.

\begin{tabular}{lllll} 
Run & Conv. (\%) & VI yield (\%) & VII yield (\%) & VIII yield (\%) \\
\hline 1 & 45 & 37 & 6 & 2 \\
$2^{\text {a }}$ & 50 & 41 & 6 & 3 \\
$3^{\text {a }}$ & 69 & 62 & 5 & 2 \\
$4^{\text {a }}$ & 68 & 59 & 6 & 3 \\
$5^{\text {a }}$ & 60 & 53 & 4 & 3 \\
$6^{\text {a }}$ & 62 & 54 & 5 & 3 \\
\hline
\end{tabular}

Substrate $=5.2 \mathrm{mmol}$; substrate $/ \mathrm{Rh}$ (molar ratio)=500/1; Rh/(L)-Cysteine (molar ratio $)=1 / 2$; aqueous buffer sol. $/$ toluene $=4 / 2 \mathrm{ml} ; \mathrm{p}\left(\mathrm{H}_{2}\right)=5 \mathrm{MPa} ; T=80^{\circ} \mathrm{C} ; t=24 \mathrm{~h}$.

a Reaction carried out by using the aqueous phase recovered from the previous run.

\section{Table 7}

Aqueous biphasic hydrogenation of trans-cinnamaldehyde ( $\mathbf{V})$ catalyzed by $\mathbf{R h} / \mathbf{C a p}$ at pH 7.2 in the water/toluene-ethylene glycol system.

\begin{tabular}{llllll}
\hline Run & Conv. (\%) & VI yield (\%) & VII yield (\%) & VIII yield (\%) & IX yield (\%) \\
\hline 1 & 71 & 66 & 4 & - & 1 \\
$2^{\text {a }}$ & 86 & 76 & 8 & - & 2 \\
$3^{\text {a }}$ & 85 & 76 & 7 & - & 2 \\
$4^{\text {a }}$ & 94 & 80 & 8 & - & 6 \\
$5^{\text {a }}$ & 95 & 80 & 8 & - & 7 \\
\hline
\end{tabular}

Substrate $=5.2 \mathrm{mmol}$; substrate $/ \mathrm{Rh}$ (molar ratio) $=500 / 1 ; \mathrm{Rh} /(\mathrm{S})$-Captopril $($ molar ratio) $=1 / 2$; aqueous buffer sol./toluene/ethylene glycol $=4 / 2 / 0.5 \mathrm{ml} ; \mathrm{p}\left(\mathrm{H}_{2}\right)=5 \mathrm{MPa}$; $T=80^{\circ} \mathrm{C} ; t=24 \mathrm{~h}$.

a Reaction carried out by using the aqueous phase recovered from the previous run.

phase was separated, dried on $\mathrm{Na}_{2} \mathrm{SO}_{4}$ and analyzed by GC (HP1 column $30 \mathrm{~m} \times 0.32 \mathrm{~mm} \times 0.25 \mu \mathrm{m}$ ) and GC-MS (HP-5MS column $30 \mathrm{~m} \times 0.25 \mathrm{~mm} \times 0.25 \mu \mathrm{m})$. The catalytic aqueous phase was recycled for further experiments.

\section{Results and discussion}

A first set of hydrogenation experiments was carried out on 2-cyclohexen-1-one (I) (Scheme 1), chosen as representative
Table 9

Aqueous biphasic hydrogenation of [3-(1,3-benzodioxol-5-yl)-2-methylpropenal] (X) catalyzed by $\mathbf{R h} / \mathbf{C a p}$ at pH 7.2 in the water/2-MeTHF-ethylene glycol system.

\begin{tabular}{lllc}
\hline Run & Conv. (\%) & XI yield (\%) & XII yield (\%) \\
\hline 1 & 38 & 30 & 8 \\
$2^{\text {a }}$ & 45 & 28 & 17 \\
$3^{\text {a }}$ & 40 & 24 & 16 \\
$4^{\text {a }}$ & 36 & 22 & 14 \\
\hline
\end{tabular}

Substrate $=5.2 \mathrm{mmol} ; \quad$ substrate $/ \mathrm{Rh} \quad($ molar $\quad$ ratio $)=500 / 1 ; \quad \mathrm{Rh} /(\mathrm{S})$-Captopril (molar ratio) $=1 / 2$; aqueous buffer sol. $/ 2-\mathrm{MeTHF} /$ ethylene glycol $=4 / 2 / 0.5 \mathrm{ml}$; $\mathrm{p}\left(\mathrm{H}_{2}\right)=5 \mathrm{MPa} ; T=80^{\circ} \mathrm{C} ; t=24 \mathrm{~h}$.

a Reaction carried out by using the aqueous phase recovered from the previous run.<smiles>O=C1C=CC(I)CC1C1CCC(O)CC1</smiles>

Scheme 1. Aqueous biphasic hydrogenation of 2-cyclohexen-1-one (I).

$\alpha, \beta$-unsaturated ketone, by using catalytic solutions obtained by dissolving $\mathrm{Rh}(\mathrm{CO})_{2}$ acac and the thioligand $\mathbf{1}$ or $\mathbf{2}$ in a disareated phosphate buffer aqueous solution ( $\mathrm{pH} 7.2)$.

The catalytic system $\mathbf{R h} / \mathbf{C y}$ gave low substrate conversions after $21 \mathrm{~h}$ at $60^{\circ} \mathrm{C}$ and $5 \mathrm{MPa}$ of $\mathrm{H}_{2}$ but increasing the reaction temperature to $80^{\circ} \mathrm{C}$ practically quantitative conversions were reached even after four recycle experiments (Table 1 ). In any case, at both 60 and $80^{\circ} \mathrm{C}$ the catalyst selectively reduced the $\mathrm{C}=\mathrm{C}$ double bond so furnishing only cyclohexanone (II).

Very interesting results were obtained by using an aqueous catalytic solution buffered at $\mathrm{pH} 10$ : the activity increased affording $24-35 \%$ conversions after only $6 \mathrm{~h}$ at $60^{\circ} \mathrm{C}$ and cyclohexanone (II) was the sole product. When the reaction was carried out for $21 \mathrm{~h}$, quantitative conversions were obtained but, besides cyclohexanone (II), also cyclohexanol (III) was also found in the reaction mixtures (8-18\%) (Table 2).

It is known that strong bases enhance the activity of the catalyst by promoting the formation of catalytically active dihydride intermediate, as demonstrated by Noyori's ruthenium-phosphine complexes [17,18]. In this case, the formation of the saturated alcohol III can be due to both the increased activity of the catalyst and to the hydrogenation of the enol of cyclohexanone formed in basic conditions. We can also hypothesize that the enhance of reactivity was also probably due to a stronger and more stable bond between rhodium and the dianionic form of the thioligand formed in alkaline medium.

\section{Table 8}

Hydrogenation of trans-cinnamaldehyde (V) catalyzed by $\mathbf{R h} / \mathbf{C a p}$ at pH 7.2 in the biphasic system water/ethylene glycol.

\begin{tabular}{|c|c|c|c|c|c|c|}
\hline Run & $t(\mathrm{~h})$ & Conv. (\%) & VI yield (\%) & VII yield (\%) & VIII yield (\%) & IX yield (\%) \\
\hline 1 & 6 & 56 & 40 & 9 & 6 & 1 \\
\hline $2^{\mathrm{a}}$ & 6 & 70 & 57 & 7 & 5 & 1 \\
\hline $3^{\mathrm{a}}$ & 6 & 72 & 60 & 6 & 5 & 1 \\
\hline $4^{\mathrm{a}}$ & 6 & 70 & 59 & 6 & 4 & 1 \\
\hline $5^{\mathrm{a}}$ & 6 & 63 & 55 & 4 & 3 & 1 \\
\hline 6 & 24 & 100 & 61 & 37 & - & 2 \\
\hline $7^{\mathrm{a}}$ & 24 & 100 & 66 & 32 & - & 2 \\
\hline $8^{a}$ & 24 & 100 & 69 & 29 & - & 2 \\
\hline $9^{a}$ & 24 & 100 & 72 & 25 & - & 3 \\
\hline $10^{\mathrm{a}}$ & 24 & 100 & 70 & 26 & - & 3 \\
\hline
\end{tabular}

Substrate $=5.2 \mathrm{mmol}$; substrate $/ \mathrm{Rh}($ molar ratio $)=500 / 1 ; \mathrm{Rh} /(\mathrm{S})$-Captopril ( molar ratio $)=1 / 2 ;$ aqueous buffer sol. $/$ ethylene glycol $=4 / 0.5 \mathrm{ml} ; \mathrm{p}\left(\mathrm{H}_{2}\right)=5 \mathrm{MPa} ; \mathrm{T}=80^{\circ} \mathrm{C}$.

a Reaction carried out by using the aqueous phase recovered from the previous run. 
<smiles>O=C/C=C/c1ccccc1</smiles>

V

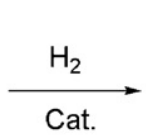

VI

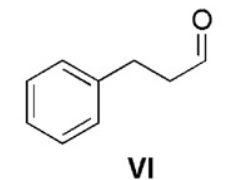

$+$<smiles>OCCCc1ccccc1</smiles>

VII<smiles>OC/C=C/c1ccccc1</smiles>

VIII

Scheme 2. Aqueous biphasic hydrogenation of trans-cinnamaldehyde (V).

We pursued our investigation by using the catalytic system $\mathbf{R h} /$ Cap, always at $60^{\circ} \mathrm{C}$ and $5 \mathrm{Mpa}$ for $21 \mathrm{~h}$, in a neutral environment (Table 3).

This catalyst was much more active than $\mathbf{R h} / \mathbf{C y}$, affording complete substrate conversions even after four recycle experiments: in all cases, mixtures of cyclohexanone (II), the prevailing reaction product, and cyclohexanol (III) were obtained. It is noteworthy that the amount of cyclohexanol (III), that in the two first runs exceeds $30 \%$, slowly tends to decrease gradually as the catalyst is recycled, due to some deactivation of the catalyst itself that becomes less active but more selective. The reaction was carried out also for a shorter time ( $1 \mathrm{~h})$ : the catalytic system showed a very good activity (70-90\% conversions) with a complete selectivity to cyclohexanone (II) (Table 3).

Owing to the good results obtained with this catalytic system we carried out some hydrogenation experiments under the above reaction conditions but at $0.5 \mathrm{Mpa}$ of $\mathrm{H}_{2}$ (Table 4).

Even at low hydrogen pressure the catalytic system was very efficient: however, from the second recycle experiment, we can observe a gradual decrease in activity leading to $75 \%$ of conversion at the fourth recycle of the catalyst. It is interesting to note that the pressure decrease leads to exclusive formation of cyclohexanone (II).

It is noteworthy the great stability of both catalytic systems $\mathbf{R h} / \mathbf{C y}$ and $\mathbf{R h} / \mathbf{C a p}$ in the aqueous phase: in fact, when these catalysts were employed in cyclohexenone (I) hydrogenation in homogeneous phase, by using toluene as the sole solvent, not only their activities were lower than in the aqueous biphasic system but also an extensive decomposition of the catalysts was observed. As a matter of fact, the catalytic system $\mathbf{R h} /$ Cap was employed to hydrogenate 2-cyclohexen-1-one (I) in toluene at $50{ }^{\circ} \mathrm{C}$ and $5 \mathrm{MPa}$ : after $22 \mathrm{~h}$ cyclohexanone (II) was obtained in only $3 \%$ yield and the catalyst decomposed affording a dark brown precipitate. When the same reaction was carried out in the presence of the catalytic system $\mathbf{R h} / \mathbf{C y}$, cyclohexanone (II) was obtained in $67 \%$ yield but the rhodium complex was transformed into black metallic rhodium.

Analogous complexes of Iridium were used in the hydrogenation process, too. The catalytic system $\mathbf{I r} / \mathbf{C y}$, employed in the hydrogenation of $\mathrm{I}$ at $80^{\circ} \mathrm{C}$ and $5 \mathrm{MPa}$ of $\mathrm{H}_{2}$ for $21 \mathrm{~h}$, was less active than $\mathbf{R h} / \mathbf{C y}$, affording only about $15 \%$ of cyclohexanone (II). In order to increase the reaction yield, we carried out some experiments under the above reaction conditions but in an aqueous solution buffered at pH 10: also in this case, the catalytic activity was strongly enhanced, leading to very high substrate conversions even after four recycle experiments (Table 5).

In line with what observed with the rhodium catalyst, Ir/Cy, used in an alkaline environment, promoted also the formation of cyclohexanol (III) that maximum reached 23\% (experiment 4). Analogously to $\mathbf{R h} / \mathbf{C y}$, also $\mathbf{I r} / \mathbf{C y}$ showed a good stability in all the recycle experiments and no leaching phenomenon was observed using a simple experimental test. In this context, the recovered organic phases were used as catalyst in the hydroformylation of styrene at $80^{\circ} \mathrm{C}$ and $80 \mathrm{~atm}$ of syngas $\left(\mathrm{CO} / \mathrm{H}_{2}=1 / 1\right)$ for $17 \mathrm{~h}$ : in all cases, hydroformylation products were never found in the reaction mixtures, so evidencing the absence of catalyst in the organic phase. In fact the catalyst present in the aqueous phase, on the contrary, was active in this reaction at the same experimental conditions. Also $\mathbf{I r} /$ Cap, obtained by interaction of $\left[\operatorname{Ir}(\mathrm{COD}) \mathrm{Cl}_{2}\right.$ with
(S)-Captopril, showed a good catalytic activity at $60^{\circ} \mathrm{C}$ and $5 \mathrm{Mpa}$ of $\mathrm{H}_{2}$, but much lower than that of the related rhodium complex: substrate conversions were in a range of about $60-70 \%$ and cyclohexanone (II) was almost the exclusive reaction product being cyclohexanol (III) produced in very small amounts (about 2-3\%). Attempts to perform the same reaction at $0.5 \mathrm{MPa}$ gave very disappointing results, conversions did not exceed $12 \%$.

Interesting results were obtained in the hydrogenation of transcinnamaldehyde (V), too (Scheme 2 ).

The selective hydrogenation of $\alpha, \beta$-unsaturated aldehydes is a challenging problem and it strongly depends on the nature of the active metal catalyst and on the hydrogenation reaction conditions ( $\mathrm{pH}$, catalyst concentration, ligand amount, etc.) [19-23]. The well-known $\mathrm{Rh}(\mathrm{I}) / \mathrm{TPPTS}$ complex, employed in the famous Ruhrchemie/Rhône-Poulenc biphasic process for the hydroformylation of propene [4-7], hydrogenates $\alpha, \beta$-unsaturated aldehydes into the corresponding saturated aldehydes, without decarbonylation, as in the case of cinnamaldehyde that can be selectively reduced to 3-phenylpropanal [19,24,25]. Recently we reported some results obtained in cinnamaldehyde hydrogenation by using the catalytic system $\mathrm{Rh}(\mathrm{CO})_{2} \mathrm{acac} / \mathrm{TPPTS}$ in the biphasic system water/toluene, at $60^{\circ} \mathrm{C}$ and $5 \mathrm{MPa}$ of $\mathrm{H}_{2}$ for $22 \mathrm{~h}$ : practically quantitative conversions were obtained but, even if 3-phenylpropanal (VI) was the main product, alcohols VII and VIII were formed, too [11]. Indeed, the hydrogenation of $\alpha, \beta$-unsaturated aldehydes, in particular trans-cinnamaldehyde, is an important process for the production of some useful fine chemicals as intermediates for the synthesis of pharmaceuticals, additives for food flavours and valuable building blocks for fragrances [24]. First we tested the activity of the catalytic system $\mathbf{R h} / \mathbf{C y}$ at $80^{\circ} \mathrm{C}$ and $5 \mathrm{MPa}$ of $\mathrm{H}_{2}$ for $24 \mathrm{~h}$ at pH 7.2 (Table 6).

$\mathbf{R h} / \mathbf{C y}$ showed a fairly good catalytic activity and, as expected, the main reaction product was 3-phenylpropanal (VI): in all the experiments small amounts of both cinnamyl alcohol (VIII) and the saturated alcohol VII were formed, too. Hydrogenations were carried out also in the presence of the catalyst $\mathbf{R h} / \mathbf{C a p}$ under the above reaction conditions and the results are fully comparable with those obtained in the presence of $\mathbf{R} \mathbf{h} / \mathbf{C} \mathbf{y}$ regarding both conversion and selectivity. As the latest experiments had not met our expectations, we carried out some $\mathbf{R h}$ /Cap catalyzed hydrogenations by adding a small volume $(0.5 \mathrm{ml})$ of ethylene glycol to toluene, normally used as solvent of the organic phase: it is known that the use of cosolvents as alcohols increases the interfacial contact between the aqueous phase and the organic one, so allowing a better interaction between the catalytic system and the substrate [26]. Actually, by using ethylene glycol it was possible to considerably increase the substrate conversion: again, the saturated aldehyde VI was the main reaction product, being the corresponding alcohol VII formed in small amounts, while cinnamyl alcohol (VIII) was completely absent (Table 7). It is interesting to note that the acetal IX (Fig. 2) was always produced, even if in small concentration, but the corresponding saturated acetal was never detected in the reaction mixtures.

Considering the positive effect played by the co-solvent, we carried out some hydrogenation experiments by using ethylene glycol as the sole organic solvent. The catalytic activity was strongly influenced, affording quantitative substrate conversions even after four recycle experiments: besides aldehyde VI, the main reaction prod- 
<smiles>C(=C/C1OCCO1)\c1ccccc1</smiles>

IX

Fig. 2. Acetal IX.

uct, also alcohol VII was formed (25-37\%), while acetal IX, always present in the reaction mixtures, did not exceed 3\% (Table 8 ). Also in this case IX did not undergo the hydrogenation process. By carrying out the reaction for only $6 \mathrm{~h}$, conversions of $56-72 \%$ were obtained: in this case, besides the above mentioned hydrogenation products and the acetal IX, present in very small amount (1\%), also the unsaturated alcohol VIII was detected in the reaction mixtures (Table 8).

Finally, as both (L)-Cysteine and (S)-Captopril are enantiomerically pure compounds, we valuated if the catalytic systems employed were capable of producing optically active products. With this purpose we chose as prochiral substrate the unsaturated aldehyde $\mathbf{X}$, precursor of the valuable fragrance Helional ${ }^{\circledR}(\mathbf{X I})$ (Scheme 3): this product is currently commercialized as a racemate but it has been demonstrated that the $(\mathrm{S})$-isomer is more powerful than the (R)-one [27].

The only catalytic system capable to hydrogenate $\mathbf{X}$ was $\mathbf{R h} / \mathbf{C a p}$, reaching at maximum 30\% conversion, with formation of both saturated aldehyde $\mathbf{X I}$ and the corresponding alcohol XII; by using 2-methyltetrahydrofurane/ethylene glycol as organic solvent instead of toluene it was possible to moderately increase the substrate conversion (Table 9).

The reaction mixtures, recovered from experiments 1 and 2 , respectively, after treatment with $\mathrm{NaBH}_{4}$ to reduce aldehyde XI to alcohol XII, were analyzed by chiral HPLC, using a CHIRALCEL OD $(250 \mathrm{~mm} \times 10 \mu \mathrm{m} \times 4.6 \mathrm{~mm})$ column and a mixture of $n$-hexane/propanol (95/5) as eluant. Very interestingly, while the product obtained in the first experiment was practically a racemate $(e e=2 \%)$ the enantiomeric excess measured on the mixture obtained in the recycle experiment was about $14 \%$ : the prevailing form was the (R)-enantiomer. Although this result is absolutely disappointing, it is noteworthy the increase of both activity and enantioselectivity after recycling of the catalyst, probably due to a change in the structure of the catalyst. A deeper investigation using NMR could probably help to support this hypothesis: we think that a bidentate thioligand coordination on Rh vs a monodentate coordi- nation, due only to SH group, could increase the steric hindrance of the complex and facilitate the creation of a chiral backbone nearer to the metal. As a consequence, an increase of the difference of energy of the transition states involving the two enantiofaces of carbon-carbon double bond is expected. The prevailing enantiomer obtained by using (S)-Captopril as thioligand was the (R)-isomer: according to the market interest for (S)-enantiomer, it would be necessary to use ( $R$ )-Captopril, that is a by-product of the synthesis of pharmaceutically active ingredient of $(\mathrm{S})$ configuration; however, in any case, the observed e.e. is still too low.

\subsection{Characterization of $\mathbf{R h} / \mathbf{C y}$ and $\mathbf{R h} / \mathbf{C a p}$}

Aiming to get some information on the coordination between the metal centre and these water soluble thioligands, we carried out a preliminary and merely explorative NMR study on the catalytic systems $\mathbf{R h} / \mathbf{C y}$ and $\mathbf{R h} / \mathbf{C a p}$, respectively, dissolved in disareated deuterated water. NMR spectra of both free (L)-Cysteine (1) and (S)-Captopril (2), in $\mathrm{D}_{2} \mathrm{O}$, were carried out, too, and the main changes in NMR spectra of these thioligands, in the presence or not of $\mathrm{Rh}(\mathrm{CO})_{2}$ acac, are reported in Table 10 . The ${ }^{1} \mathrm{H}-\mathrm{NMR}$ spectrum of (L)-Cysteine showed multiplets at 2.88-3.06 ppm and at 3.87-3.91 ppm assigned to $-\mathrm{CH}_{2}$ and $-\mathrm{CH}$ protons, respectively. The ${ }^{1} \mathrm{H}$-NMR spectrum of the complex $\mathbf{R h} / \mathbf{C y}$ obtained by reacting $\mathrm{Rh}(\mathrm{CO})_{2}$ acac with (L)-Cysteine in a molar ratio $1 / 2$, showed a clear shifting and splitting of these signals as compared with the spectrum of the free aminoacid. In particular, the peaks of the protons of the $-\mathrm{CH}_{2}$ moiety were shifted from $2.88-3.06$ to $3.05-3.34 \mathrm{ppm}$ and those assigned to the $-\mathrm{CH}$ group from 3.87-3.91 to 4.00-4.06 ppm. Moreover, the ${ }^{13} \mathrm{C}$-NMR spectrum of the complex $\mathbf{R h} / \mathbf{C y}$ showed, as compared with the spectrum of free Cysteine, a shift from 36.7 to $42.3 \mathrm{ppm}$ for the signal assigned to the carbon atom bound to $-\mathrm{SH}$ and from 49.5 to $68.9 \mathrm{ppm}$ for the carbon atom bound to the amino group. On the basis of these results, we can assume that the shifting of the aminoacid peaks is due to the proximity of the rhodium and we can hypothesize the formation of a chelate complex due to an interaction of the rhodium atom with both sulfur and nitrogen. In order to further support our hypothesis, FT-IR spectra of $\mathbf{R h} / \mathbf{C y}$ complex and of the free aminoacid in the range of $4000-600 \mathrm{~cm}^{-1}$ were recorded. We could observe that the band present in the Cysteine spectrum at $2550 \mathrm{~cm}^{-1}$, due to the $\mathrm{S}-\mathrm{H}$ stretching, was absent in the $\mathbf{R h} / \mathbf{C y}$ spectrum, so confirming the Rh-S interaction; moreover, the strong band at $3427 \mathrm{~cm}^{-1}$ possibly indicated a coordination of the amino group to the metal atom [28]. An analogous study was carried out on the catalytic system Rh/Cap. The ${ }^{1} \mathrm{H}-$<smiles>[X]/C(C=O)=C\c1ccc2c(c1)OCO2</smiles>

Scheme 3. Aqueous biphasic hydrogenation of [3-(1,3-benzodioxol-5-yl)-2-methylpropenal] (X).

Table 10

Main changes in NMR spectra of the thioligands (L)-Cysteine (1) and (S)-Captopril (2) in presence or not of $\mathrm{Rh}(\mathrm{CO})_{2} \mathrm{acac}$.

\begin{tabular}{llll}
\hline NMR & Free $[(\mathrm{L})$-Cysteine] $(\mathrm{ppm})$ & Group & $(\mathrm{L})$-Cysteine in the presence of Rh(CO) ${ }_{2}$ acac $(\mathrm{ppm})$ \\
\hline${ }^{1} \mathrm{H}-\mathrm{NMR}$ & $3.91-3.87$ & $-\mathrm{CH}-$ & $4.06-4.00$ \\
${ }^{1} \mathrm{H}-\mathrm{NMR}$ & $3.06-2.88$ & $-\mathrm{CH}_{2}-$ & $3.34-3.05$ \\
${ }^{13} \mathrm{C}-\mathrm{NMR}$ & 49.5 & $-\mathrm{CH}_{-} \mathrm{NH}_{2}$ & 68.9 \\
${ }^{13} \mathrm{C}-\mathrm{NMR}$ & 36.7 & $-\mathrm{CH}_{2}-\mathrm{SH}$ & 42.3 \\
& & & $(\mathrm{~S})$-Captopril in the presence of Rh(CO) $)_{2}$ acac $(\mathrm{ppm})$ \\
$\mathrm{NMR}$ & Free $[(\mathrm{S})$-Captopril] $(\mathrm{ppm})$ & & $4.18-4.15(\mathrm{splitting}$ of the signals) \\
${ }^{1} \mathrm{H}-\mathrm{NMR}$ & $4.14-4.10$ & $-\mathrm{CH}-\mathrm{COOH}$ & $2.50-2.40$ \\
${ }^{1} \mathrm{H}-\mathrm{NMR}$ & $2.20-2.10$ & $-\mathrm{CH}_{2}-\mathrm{SH}$ & \\
\hline
\end{tabular}


NMR spectrum of (S)-Captopril showed a quartet at 4.14-4.10 ppm assigned to the proton of $-\mathrm{CH}$ in $\alpha$-position to the carboxylic moiety: because of an axial and an equatorial conformation, this proton can couple with the two protons of $-\mathrm{CH}_{2}$ in $\beta$-position to $-\mathrm{COOH}$, giving two doublets with the same coupling constant. The ${ }^{1} \mathrm{H}-\mathrm{NMR}$ spectrum of the complex obtained by reacting $\mathrm{Rh}(\mathrm{CO})_{2}$ acac with (S)-Captopril in a molar ratio $1 / 2$, besides a slight shift of the above signal from 4.14-4.10 ppm to $4.18-4.15 \mathrm{ppm}$, showed also a splitting of this signal in two doublets with different coupling constants. Moreover, we could observe a shift of the signal assigned to the $-\mathrm{CH}_{2}$ in $\alpha$-position to the $-\mathrm{SH}$ moiety from 2.20 to $2.10 \mathrm{ppm}$ (free thioligand) to $2.50-2.40 \mathrm{ppm}$ (complex Rh/Cap). On the basis of these results, we can assume that the shifting of (S)-Captopril peaks is due to the proximity of the rhodium that probably forms a chelate complex due to an interaction of the metal atom with both sulfur and the carboxylic group.

\section{Conclusive remarks}

All the catalytic systems tested were active in the hydrogenation of some representative $\alpha, \beta$-unsaturated substrates. The precatalyst $\mathbf{R h} / \mathbf{C y}$ was very active in cyclohexenone (I) hydrogenation by carrying out the reaction at $5 \mathrm{MPa}$ of $\mathrm{H}_{2}$ pressure at $80^{\circ} \mathrm{C}$ at $\mathrm{pH} 7.2$ or at $60^{\circ} \mathrm{C}$ but in an alkaline medium. More active was the catalytic system $\mathbf{R h} /$ Cap, capable to selectively reduce cyclohexenone (I) even at low hydrogen pressure in a neutral environment. It is noteworthy that both rhodium catalysts were easily recycled without significant loss of activity. The iridium based catalysts, $\mathbf{I r} / \mathbf{C y}$ and Ir/Cap, showed an analogous trend though their activities were lower than those of the related rhodium catalysts. Both $\mathbf{R h} / \mathbf{C y}$ and $\mathbf{R h} / \mathbf{C a p}$ were active also in trans-cinnamaldehdye $(\mathbf{V})$ hydrogenation: very interestingly, the use of ethylene glycol as organic solvent or co-solvent strongly enhanced the activity of these catalytic systems. In all cases the main reaction product was the saturated aldehyde 3-phenylpropanal (VI). Finally, Rh/Cap was employed in the hydrogenation of [3-(1,3-benzodioxol-5yl)-2-methylpropenal] $(\mathbf{X})$, precursor of the fragrance Helional ${ }^{\circledR}$ : unfortunately, both substrate conversion and enantioselectivity did not give the desired result but it was noteworthy the increase, even if moderate, of both activity and enantiomeric excess after recycling of the catalyst.

\section{References}

[1] B. Cornils, W.A. Herrmann, I.T. Horvath, W. Leitner, S. Mecking, H. OlivierBourbigou, D. Vogt (Eds.), Multiphase Homogeneous Catalysis, Wiley-VCH, Weinheim, 2005.

[2] F. Joò, Aqueous Organometallic Catalysis, Kluwer Acad. Publ, Dordrecht, 2001.

[3] B. Cornils, W.A. Herrmann (Eds.), Aqueous-Phase Organometallic Catalysis, 2nd ed., Wiley-VCH, Weinheim, 2004.

[4] E.G. Kuntz, ChemTech 17 (1987) 570-575.

[5] B. Cornils, E.G. Kuntz, J. Organomet. Chem. 502 (1995) 177-186.

[6] B. Cornils, Org. Process Res. Dev. 2 (1998) 121-127.

[7] E. Kuntz, Rhône-Poulenc Ind., Fr. Pat. 2314910, 1975, DE 2627354, 1976S.

[8] M.E. Wilson, G.M. Whitesides, J. Am. Chem. Soc. 100 (1978) 306-307.

[9] Y. Watanabe, T. Ueno, S. Abe, Nagoya Industrial Science Research Institute, US 49405 (2005).

[10] T. Ueno, Y. Watanabe, M. Ohashi, T. Koshiyama, N. Yokoi, Nagoya Industrial Science Research Institute, US 96260 (2005).

[11] M. Marchetti, F. Minello, S. Paganelli, O. Piccolo, Appl. Catal. A: Gen. 373 (2010) 76-80.

[12] S. Crobu, M. Marchetti, G. Sanna, J. Inorg. Biochem. 100 (2006) 1514-1520.

[13] S. Paganelli, M. Marchetti, M. Bianchin, C. Bertucci, J. Mol. Catal. A: Chem. 269 (2007) 234-239.

14] S.G. Murray, F.R. Hartley, Chem. Rev. (1981) 365-414

[15] M. Shirai, Y. Yoshida, Ube Industries, Ltd., Japan, JP 2004269376 (2004).

[16] D.D. Perrin, L.F. Armarego, Purification of Laboratory Chemicals, 3rd ed., Pergamon Press, Oxford, 1988

[17] E.P. Cappellani, P.A. Maltby, R.H. Morris, C.T. Schweitzer, M.R. Steele, Inorg. Chem. 28 (1989) 4437-4438.

[18] T. Ohkuma, H. Ooka, S. Hashiguchi, T. Ikariya, R. Noyori, J. Am. Chem. Soc. 117 (1995) 2675-2676.

[19] J.M. Grosselin, C. Mercier, G. Allmag, F. Grass, Organometallics 10 (1991) $2126-2133$.

[20] T. Dwars, G. Oehme, Adv. Synth. Catal. 344 (2002) 239-260, and references therein.

[21] B. Chen, U. Dingerdissen, J.G.E. Krauter, H.G.J. Lansink Rotgerink, K. Mobus, D.J. Ostgard, P. Panster, T.H. Riermeier, S. Seebald, T. Tacke, H. Trauthwein, Appl. Catal. A: Gen. 280 (2005) 17-46, and references therein.

[22] F. Joò, Acc. Chem. Res. 35 (2002) 738-745.

[23] H. Gulyàs, A.C. Bényei, J. Bakos, Inorg. Chim. Acta 357 (2004) 3094-3098.

[24] K. Nuithitikul, M. Winterbottom, Chem. Eng. Sci. 59 (2004) 5439-5447.

[25] K. Nuithitikul, M. Winterbottom, Catal. Today 128 (2007) 74-79.

[26] D. Cole-Hamilton, R. Tooze (Eds.), Catalyst Separation Recovery and Recycling, Springer, Dordrecht, 2006.

[27] D. Endres, M. Backes, Tetrahedron Asymmetry 15 (2004) 1813-1817.

[28] N. Ruiz, A. Aaliti, J. Forniés-Cámer, A. Ruiz, C. Claver, C.J. Cardin, D. Fabbri, S. Gladiali, J. Organomet. Chem. 545 (1997) 79-87. 